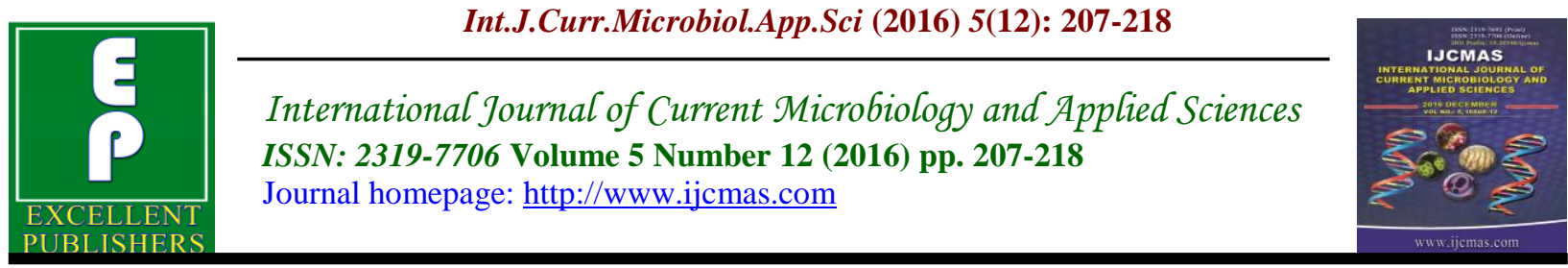

Original Research Article

http://dx.doi.org/10.20546/ijcmas.2016.512.023

\title{
Morphological Characterization of Some Wild Macrofungi of Gorakhpur District, U.P., India
}

\author{
Ravinder Pal Singh", Pratima Vishwakarma, Aradhana Pal and N.N. Tripathi \\ Bacteriology and Natural pesticide lab, Department of Botany, \\ D.D.U. Gorakhpur University, Gorakhpur, India \\ *Corresponding author
}

\begin{tabular}{|c|c|}
\hline & A B S T R A C T \\
\hline Keywords & \multirow{4}{*}{$\begin{array}{l}\text { Gorakhpur district is situated in North-East part of Uttar Pradesh in India, near the } \\
\text { border of Nepal. It harbors different types of micro climatic conditions and habitats } \\
\text { along with different kinds of vegetation, which provide suitable environment for } \\
\text { the growth of different types of macrofungi. The extensive survey was made in } \\
\text { different Tehsils of Gorakhpur district in order to know the biodiversity of wild } \\
\text { macrofungi, including edible species during the period of January, } 2014 \text { - July } \\
\text { 2016. In present study, } 20 \text { different species of macrofungi belonging to } 12 \text { genera } \\
\text { of } 9 \text { families were identified based on their morphology and microscopic } \\
\text { characteristics. Termitomyces heimii, Tuber aestivum and Macrolepiota procerc } \\
\text { were edible and found to be most abundant but Agaricus arvensis was rarely founc } \\
\text { during the survey. This study indicates that the area embrace high diversity of } \\
\text { macrofungi and their application as medicines may be exploited. }\end{array}$} \\
\hline $\begin{array}{l}\text { Macrofungi, } \\
\text { Mushrooms, } \\
\text { Diversity, } \\
\text { Wild Macrofungi } \\
\text { Abundance. }\end{array}$ & \\
\hline Article Info & \\
\hline $\begin{array}{l}\text { Accepted: } \\
\text { 12 November } 2016 \\
\text { Available Online: } \\
10 \text { December } 2016\end{array}$ & \\
\hline
\end{tabular}

\section{Introduction}

Mushrooms are seasonal fungi, which occupy diverse role in nature across the forest ecosystem. They predominantly occur during the rainy as well as spring season when the snow melts. Mushrooms are in fact the 'fruit' of the underground fungal mycelium. Macrofungi may be edible, inedible, medicinal and poisonous. Some macrofungi are not edible but they have some tonic and medicinal qualities (Chang and Miles, 2004). They are macromycetes forming macroscopic fruiting bodies such as agarics, boletes, jelly fungi, coral fungi, stinkhorns, bracket fungi, puffballs and bird's nest fungi. They are fleshy, subfleshy or sometimes leathery or woody and bear their fertile surface either on lamellae or lining the tubes, opening out by means of pores.

Fungi are the second largest biotic community after insects in world (Sarbhoy et al., 1996). Out of 1.5 million fungi around the earth, only $50 \%$ are characterized until now and one third of total fungal diversity exists in India (Butler and Bisby, 1960; Bilgrami et al., 1981, 1991; Manoharachary, 2002; Manoharachary et al., 2005). Mushrooms alone are represented by about 41,000 species, of which approximately 850 species are recorded from India (Deshmukh, 2004) mostly 
belonging to Agaricales, also known as gilled mushrooms (for their distinctive gills), or Euagarics. Various workers also identified and classified various types of macrofungi from different parts of India (Butler and Bisby, 1931; Vasudeva, 1960).

All types of mushrooms are important in decomposition processes, because of their ability to degrade cellulose and other plant polymers (Arora, 2008). Though India has rich macrofungal biodiversity, most traditional knowledge about mushrooms come from the far Eastern countries. Most of the mushrooms grow abundantly in nature and their commercial harvest is being undertaken for benefit in these countries. The mushrooms like Ganoderma, Lentinus, Grifola etc. were collected and used since time immemorial. Recent reports show a tradition of wild mushroom picking, their consumption and sale in the market in other countries (Guzman, 2008; Sitta and Floriani, 2008).

The current area of survey is Gorakhpur which is situated in North-East part of Uttar Pradesh near the border of Nepal. It covers about 3483.8 square kilometers with latitude of $26^{\circ} 13^{\prime} \mathrm{N}$ and $27^{\circ} 29^{\prime} \mathrm{N}$ and longitude of $83^{\circ} 05^{\prime}$ E. Average annual temperature is $26^{\circ} \mathrm{C}$. It ranges from $30^{\circ}-40^{\circ} \mathrm{C}$ in summer and $2^{0}-18^{0} \mathrm{C}$ in winter. Annual rainfall is $1393.1 \mathrm{~mm}$ and $87 \%$ of rainfall is recorded during period of June to September (Singh et al., 2014). The soil of the region is part of the trans-Sarju plain and comprises Gangetic alluvium brought down by rivers like Ghaghara, Rapti, Rohin and Gandak from the Himalayas in the North. The texture is sandy loam and $\mathrm{pH}$ is about neutral. The general vegetation of Gorakhpur district is interspersed with patches of forest, old fields, open pasture, uplands (mounds or dhus), lowlands, orchards, playgrounds and human settlements (Srivastava et al., 2015).
Gorakhpur region is a rich reservoir of macrofungi. Lots of work had been done in this area to explore its macrofungal diversity by various workers (Srivastava et al., 2011; Vishwakarma et al., 2014; Chandrawati et al., 2014). An attempt was made to explore the macrofungal diversity in the region emphasizing morphological features of the collected samples.

\section{Materials and Methods}

Systematic and periodical survey of different Tehsils (Sadar, Sahajanwa, Gola, Bansgaon, Khajni, Chauri-Chaura, Campierganj), associated forests and other habitats rich with organic matter of Gorakhpur district (U.P.) were visited during January, 2014 - July, 2016. The ecological habitats viz., humid soil, wood log, leaf litter, wood, sandy soil, leaf heaps, wheat straw, paddy straw, calcareous soil, wet soil, troops of rotten wood, termite nests, decaying wood $\log$ and humus were taken in consideration for their presence of macrofungi. Regular field trips were made for collection of macrofungi but it was more frequent during (June to September) monsoon season.

The collected samples were wrapped in wax paper and brought to the laboratory for the study and identification. The identification was made on the basis of macroscopic and microscopic characteristics using relevant literatures (Purakasthya, 1985; Alexopolous et al., 1996) and information available at www.mushroomexpert.com or www.mycokeys.com (Henry and Sullivan, 1969; Rapsang and Joshi, 2012). The soft textured samples were preserved in $2 \%$ formaldehyde and leathery textured samples were preserved in $4 \%$ formaldehyde. Alternately, the samples were also oven dried at $80^{\circ} \mathrm{C}$ for 5 consecutive days, wrapped in aluminum foil and packed in the 
polythene bags with naphthalene balls for further study. The traditional knowledge of the wild mushrooms like their edibility and medicinal value were also gathered from the local tribes. All the identified and unidentified specimens were deposited to the herbarium of Department of Botany, DDU Gorakhpur University, Gorakhpur, U. P. India.

\section{Data Analysis}

Frequency and density were analyzed following Gogoi and Sarma (2012).

$$
\begin{aligned}
& \text { Frequency of fungal species }(\%)=\frac{\text { No. of sites in which the sp.is present }}{\text { Total no. of sites }} \times 100 \\
& \text { Density }=\frac{\text { Total no.individual of a particular species }}{\text { Total no. of sites }}
\end{aligned}
$$

\section{Results and Discussion}

A total of 20 macrofungi belonging to 12 genera of 9 families were identified, out of which 10 species belong to family Agaricaceae. The informations regarding the species name, family, edibility and host/substratum, frequency and density of collected macrofungi are given in Table 1.

\section{Macroscopic and microscopic study of collected samples}

\section{Agaricus arvensis}

Family: Agaricaceae

Description: Cap $5 \mathrm{~cm}$ broad, broadly convex, often with a low umbo, decurved to occasionally upturned in senescent specimens, margin incurved, surface dry and smooth, fibrillose to finely scaled in dry weather, white to ashy-grey colour. Stipe $6 \mathrm{~cm}$ long, tapering to a pointed base, stuffed, veil thin, fragile, membranous, either leaving remnants on the young cap margin, temporary ring. Gills close, pink, free, becoming blackish brown at maturity. Spore 6.71 x $4.32 \mu \mathrm{m}$, smooth, spore print blackish brown.

Habitat: Found scattered in grassy areas.

Place of collection: Campierganj, Gola

Date of collection: 21-08-2015

\section{Agaricus campestris}

Family: Agaricaceae

Description: Cap $5.5 \mathrm{~cm}$ broad, convex, often with a low umbo, margin incurved, dry and smooth surface, fibrillose to finely scaled in dry weather, white to ashy grey colour. Stipe 5 $\mathrm{cm}$ long, tapering to pointed base, veil thin, membranous, fragile, either leaving remnants on the young cap margin or forming a median to superior, evanescent ring. Gills close, pink, free, becoming blackish brown at maturity. Spore $6.5 \times 4.31 \mu \mathrm{m}$.

Habitat: Scattered or forming arcs and rings in grassy areas.

Place of collection: Sadar

Date of collection : 17-03-2015 


\section{Agaricus trisulpharatus}

Family: Agaricaceae

Description: Cap $3 \mathrm{~cm}$ broad, bell-shaped then umbonate and flat, margin distinctly lined in mature specimens, bright yellow to greenish yellow or pale yellow or white. Gills free, yellow or pale yellow, crowded. Stipe $5 \mathrm{~cm}$ long, dry or powdery, slender, smooth but slightly enlarged at the base, yellow. Veil yellow, partial veil forms a small, collar-like ring on the upper stalk which may disappear. Flesh very thin, yellow. Spores ellipsoid, with an apical pore, smooth, $9.40 \times 5.51 \mu \mathrm{m}$.

Habitat: Found single or in bunch on rich organic matter, decaying hay and leaf piles.

Place of collection: Campierganj, Shahjanwa, Sadar

Date of collection: $22-09-2015$

\section{Amanita cokeri}

Family : Amanitaceae

Description: Cap $8 \mathrm{~cm}$ broad, expanding to convex, oval, dry or sticky when wet, pointed and white, the margin not lined. Stipe $12 \mathrm{~cm}$ long, tapering slightly to apex, white, bald above or somewhat shaggy, with a fairly large basal bulb that is shallowly "rooted", with more or less concentric zones of distinctive, down-turned scales on the upper bulb and lower stem, sometimes bruising and staining reddish or rusty, especially on the bulb. Gills free from the stem or slightly attached to it, nearly distant, white or creamy, with frequent shortgills. Spores 10.99 x $6.88 \mu \mathrm{m}$.

Habitat: Found single or scattered on the ground under hardwood trees.

Place of collection: Campierganj, Khajni, Sadar

Date of collection: $21-07-2015$

\section{Amanita fulva}

Family : Amanitaceae

Description: Cap $4 \mathrm{~cm}$ across, expanding to almost flat with a low umbo and a distinctly grooved margin, ovoid at first, orange or brown, slightly paler toward the margin, smooth, slightly sticky when moist then dry. Gills free, close, broad, white to creamy. Stipe $5 \mathrm{~cm}$ long, hollow, slender, quite fragile, tapering toward the top, white tinged with orange or brown and very fine white hairs, no ring, but base of stem encased in large baglike volva, white tinged with orange-brown. Flesh white. Spores 10.5 x $9.7 \mu \mathrm{m}$, globose, nonamyloid.

Habitat: Found singly or in small groups on litter soil.

Place of collection: Gola

Date of collection: 11-08-2015

\section{Auricularia auricula judae}

Family : Auriculariaceae

Description: Fruit body $5 \mathrm{~cm}$ across, ear-shaped, gelatinous when fresh drying hard and horny, outer surface tan-brown with minute greyish downy hairs, inner surface grey-brown, smooth or often wrinkled and ear-like. Spores white, sausage-shaped, 17.8 x $7.3 \mu \mathrm{m}$.

Habitat: Found on branches of trees, usually dead wood.

Place of collection: Campierganj, Shahjanwa, Sadar

Date of collection: $17-06-2014$ 


\section{Coprinus comatus}

Family : Agaricaceae

Description: Cap $3 \mathrm{~cm}$ across, more or less a tall ovoid when young, white and very shaggyscaly, becoming more cylindrical as it expands, often with a pale brownish "skullcap" at apex. Gills free, very narrow, crowded, white becoming black and inky from the margin upward. Stipe $5 \mathrm{~cm}$ long, straight, with a slightly bulbous base, hollow in center, white, smooth, with a ring of veil tissue left lower down on the stem. Flesh soft, fibrous and white. Spores 14.3 x $8.4 \mu \mathrm{m}$, ellipsoid, smooth.

Habitat: Found on roadsides, lawns and other urban sites.

Place of collection: Sadar, Gola

Date of collection: $20-08-2014$

\section{Coprinus domesticus}

Family : Agaricaceae

Description: Cap $3 \mathrm{~cm}$ across, ovoid at first expanding convex or bell-shaped, splitting at margin, pale buff with darker tawny centre powdered at first with whitish or buff remains of veil, later smooth and becoming grooved from the margin inwards. Stipe $7 \mathrm{~cm}$ long, swollen at base, white tinged buff towards the ridged base. Gills white at first rapidly purplish date then black. Spore print dark brown. Spores cylindric ellipsoid, 9.5 x $4.5 \mu \mathrm{m}$.

Habitat: Found on dead wood of broad-leaved trees.

Place of collection: Bansgaon

Date of collection: $23-07-2014$

\section{Coprinus extinctorius}

Family : Agaricaceae

Description: Cap $3.5 \mathrm{~cm}$ across, cylindrical-ovate to conical, broadly bell-shaped when expanded, white then sepia-grey finally black covered in white to clay-pink patches of veil remnant. Stipe $8 \mathrm{~cm}$ long, with woolly bulbous base, white. Gills white then clay-pink, finally black and deliquescing. Spore print black. Spores ellipsoid, 13.4 x11 $\mu \mathrm{m}$.

Habitat: Found scattered on leaf litter.

Place of collection: Bansgaon

Date of collection: $20-08-2014$

\section{Daldinia concentric}

Family : Xylariaceae

Description: Fruit body $5 \mathrm{~cm}$ across, hemispherical to subglobose, brown at first soon black and shiny. Flesh concentrically zoned silver-grey and blackish. Spores black elliptical to fusiform, $13.05 \times 7.3 \mu \mathrm{m}$.

Habitat: Saprobic on decaying wood log.

Place of collection: Shahjanwa, Sadar, Campierganj

Date of collection: $20-03-2014$

\section{Daldinia vernicosa}

Family : Xylariaceae

Description: Fruit body $4.5 \mathrm{~cm}$ across, hemispherical to subglobose, brown at first soon black and shiny or more in extent and is black and carbonaceous at maturity. The spores are 
about the same size but are somewhat smaller and less variable in size. Spores black, $11.8 \mathrm{x}$ $7.5 \mu \mathrm{m}$.

Habitat: Saprobic on decaying wood log.

Place of collection: Sadar

Date of collection: $15-06-2014$

\section{Leucoagaricus americanus}

Family : Agaricaceae

Description: Cap $8 \mathrm{~cm}$ broad, oval and broadly convex then flat with an umbo, background whitish at first, then reddening when mature, dry and smooth, reddish-brown or dingy pinkish-buff scales. Gills free, close, broad, white staining pinky-buff. Stipe $11 \mathrm{~cm}$ long, often enlarged at or below the middle and tapering toward the base, white at first, staining or aging pinkish or reddish brown, smooth with adpressed silky hairs. Flesh thick, white staining yellowish then reddish brown. Spores broadly ellipsoid, smooth, dextrinoid, $9.8 \mathrm{x}$ $7.5 \mu \mathrm{m}$.

Habitat: Found singly or in dense clusters in fields on leaf litter.

Place of collection: Sadar, Campierganj

Date of collection: $23-08-2015$

\section{Leucoagaricus leucothites}

Family : Agaricaceae

Description: Cap $7 \mathrm{~cm}$ broad, convex expanding to almost flattened, smooth and silky, whitish becoming flushed flesh colour or pale cream. Stipe $10 \mathrm{~cm}$ long, concolorous with the cap, ring concolorous, narrow, free of the stem. Flesh thick and white in the cap, browning in the stem. Taste and smell not distinctive. Gills white becoming pale flesh colour with age. Spore print white. Spores ovoid, dextrinoid, 8.5 x $4.8 \mu \mathrm{m}$.

Habitat: Found in gardens or at roadsides.

Place of collection: Gola

Date of collection: $19-08-2015$

\section{Macrolepiota procera}

Family: Agaricaceae

Description: Cap $10 \mathrm{~cm}$ across, button spherical or egg-shaped expanding flattened with a prominent umbo, pale buff or grey-brown covered in darker shaggy scales. Stipe $13 \mathrm{~cm}$ long, white, with a grey-brown felty covering which becomes split into snake-like markings as the stem expands, ring large, white on upper surface, brown below, movable on the stem. Flesh thin, soft, white. Taste sweet, smell slight indistinctive. Gills free, white. Spore print white. Spores ovate with a germ-pore, dextrinoid, $17.2 \times 11.5 \mu \mathrm{m}$.

Habitat: Found in field on grassy area.

Place of collection: Sadar, Gola, Campierganj, Chauri-Chaura

Date of collection: 2-07-2014

\section{Macrolepiota rhacodes}

\section{Family : Agaricaceae}

Description: Cap $10 \mathrm{~cm}$ broad, ovate then expanding to almost flat, disrupting into broad, pallid, often slightly reflexed scales on a fibrous background, giving the cap a shaggy, torn 
appearance. Stem $12 \mathrm{~cm}$ long, thickened towards the bulb which is usually oblique, whitish tinged dirty pinkish-brown, bruising reddish brown when fresh. Flesh white becoming orange to carmine red on cutting. Taste pleasant, smell strongly aromatic. Gills white, tinged reddish in older specimens, bruising reddish. Spore print white. Spores elliptical with germpore, dextrinoid, $10.48 \times 7.4 \mu \mathrm{m}$.

Habitat: Found singly or in group on grassy area.

Place of collection: Bansgaon, Sadar, Gola, Campierganj, Chauri-Chaura

Date of collection: $12-08-2015$

\section{Panaeolus ater}

Family : Bolbitiaceae

Description: Cap $3 \mathrm{~cm}$ across, hemispherical with slight umbo, dark brown when moist drying buff or tan from margin inwards. Stipe $12 \mathrm{~cm}$ long, buff or tan to darker brown, paler at apex, base covered in fine white down. Flesh thin, brown. Taste not distinctive, smell none. Gills adnate, grey at first soon becoming mottled black then finally totally black. Spore print black. Spores lemon-shaped, 11.7 x $7.8 \mu \mathrm{m}$.

Habitat: Found on lawns or in short grass under trees.

Place of collection: Sadar, Gola

Date of collection: 2-01-2015

\section{Phallus duplicates}

Family : Phallaceae

Description: Fruit body starting as a large white "egg" $5 \mathrm{~cm}$ across, then rupturing to release the spongy stem and head. Head bell-shaped, deeply pitted-reticulate, attached to stem at center by a white circlet surrounding the open pore at top of stem, lower margin of head is free with a prominent yellow net like indusium. Stem $12 \mathrm{~cm}$ long, hollow, of a cellular, sponge-like structure; white. Spores ellipsoid, smooth, 4.2 x $1.8 \mu \mathrm{m}$.

Habitat: Found on moist soil.

Place of collection: Shahjanwa, Sadar

Date of collection: $12-08-2015$

\section{Russula emeticella}

Family : Russulaceae

Description: Cap $5 \mathrm{~cm}$ broad, convex, later flattening or with a shallow depression, scarlet, cherry or blood red, sometimes with ochre-tinted to white areas, somewhat thin-fleshed, fragile, shiny, sticky when moist, skin easily peeling to show pink to red coloured flesh beneath, margin often furrowed when old. Stipe $6 \mathrm{~cm}$ long, white, cylindrical or more usually somewhat swollen towards the base, fragile. Flesh white, red immediately beneath cap cuticle. Taste very hot, smell slightly fruity. Gills adnexed to free, cream then pale straw. Spore print whitish. Spores broadly ovoid, with large warts, 9.46 x $8.22 \mu \mathrm{m}$.

Habitat: Found scattered on litter.

Place of collection: Chauri-Chaura

Date of collection: 22-09-2015 


\section{Termitomyces heimii}

Family : Lyophyllaceae

Description: Pileus $2 \mathrm{~cm}$ across, plane to convex with prominent umbo, whitish in colour, surface smooth, viscid when moist. Stipe $16 \mathrm{~cm}$ height, cylindrical, more or less equal, whitish in colour, pseudorrhiza long, annulus single layered, thick, white, superior. Gills free, white, margin serrulate, crowded. Spores $7.61 \times 4.11 \mu \mathrm{m}$.

Habitat: Found on moist soil and in association with termitorium.

Place of collection: Sadar, Gola, Bannsgaon, Campierganj, Chauri-Chaura, Shahjanwa

Date of collection: $13-09-2014$

\section{Tuber aestivum}

Family : Tuberaceae

Description: Fruit body $6 \mathrm{~cm}$ across, globose, covered in pyramidal warts, blackish brown. Flesh whitish becoming marbled grey-brown. Taste nutty, smell sweet. Spores ovoid, reticulate, $7.61 \times 7.10 \mu \mathrm{m}$.

Habitat: Found buried usually under hardwood trees.

Place of collection: Sadar, Gola, Khajni, Bannsgaon, Campierganj, Chauri-Chaura, Shahjanwa

Date of collection: $20-09-2014$

Table.1 Frequency and density of collected macrofungal species during survey period are listed below

\begin{tabular}{|c|c|c|c|c|}
\hline Macrofungal species & Family & Edibility & $\begin{array}{c}\% \\
\text { Frequency }\end{array}$ & Density \\
\hline Agaricus arvensis Schaeff. & Agaricaceae & Edible & 28.57 & 0.28 \\
\hline A. campsetris $\mathrm{L}$. & Agaricaceae & Edible & 14.28 & 0.14 \\
\hline A. trisulpharatus Berk. & Agaricaceae & Edible & 42.85 & 0.57 \\
\hline $\begin{array}{l}\text { Amanita cokeri E.-J. Gilbert and Kühner ex. } \\
\text { E.-J. Gilbert }\end{array}$ & Amanitaceae & Poisonous & 57.14 & 1.57 \\
\hline A. fulva Fr. & Amanitaceae & Edible & 14.28 & 0.14 \\
\hline Auricularia auricula judae (Bull.) Quẻl. & Auriculariaceae & Medicinal & 42.85 & 0.42 \\
\hline Coprinus comatus (O.F.Müll.) Pers. & Agaricaceae & Choicely edible & 42.85 & 1.00 \\
\hline C. domesticus (Bolton) Gray & Agaricaceae & Inedible & 14.28 & 1.00 \\
\hline C. extinctorius $\mathrm{Fr}$. & Agaricaceae & Inedible & 14.28 & 0.14 \\
\hline $\begin{array}{l}\text { Daldinia concentrica (Bolton) Cesati and De } \\
\text { Notaris }\end{array}$ & Xylariaceae & Medicinal & 42.85 & 1.71 \\
\hline D. vernicosa Cesati and De Notaris & Xylariaceae & Medicinal & 14.28 & 0.42 \\
\hline Leucoagaricus americanus (Peck) Vellinga & Agaricaceae & Edible & 28.57 & 0.57 \\
\hline L. leucothites (Vitt.) Wasser & Agaricaceae & Edible & 14.28 & 0.42 \\
\hline Macrolepiota procera (Scop.) Singer & Agaricaceae & Edible & 57.14 & 1.85 \\
\hline M. rhacodes (Vitt.) Singer & Agaricaceae & Choicely edible & 85.71 & 2.14 \\
\hline Panaeolus ater (Lange) Kuhn. and Romagn. & Bolbitiaceae & Inedible & 28.57 & 1.28 \\
\hline Phallus duplicates Bosc & Phallaceae & Medicinal & 28.57 & 1.14 \\
\hline Russula emeticella (Sing.) Romagn. & Russulaceae & Edible & 14.28 & 0.14 \\
\hline Termitomyces heimii Natrajan & Lyophyllaceae & Edible & 71.42 & 3.57 \\
\hline Tuber aestivum Vitt. & Tuberaceae & Edible & 85.71 & 4.28 \\
\hline
\end{tabular}


Fig.1 The Map shows various sampling locations in different Tehsils of Gorakhpur district.

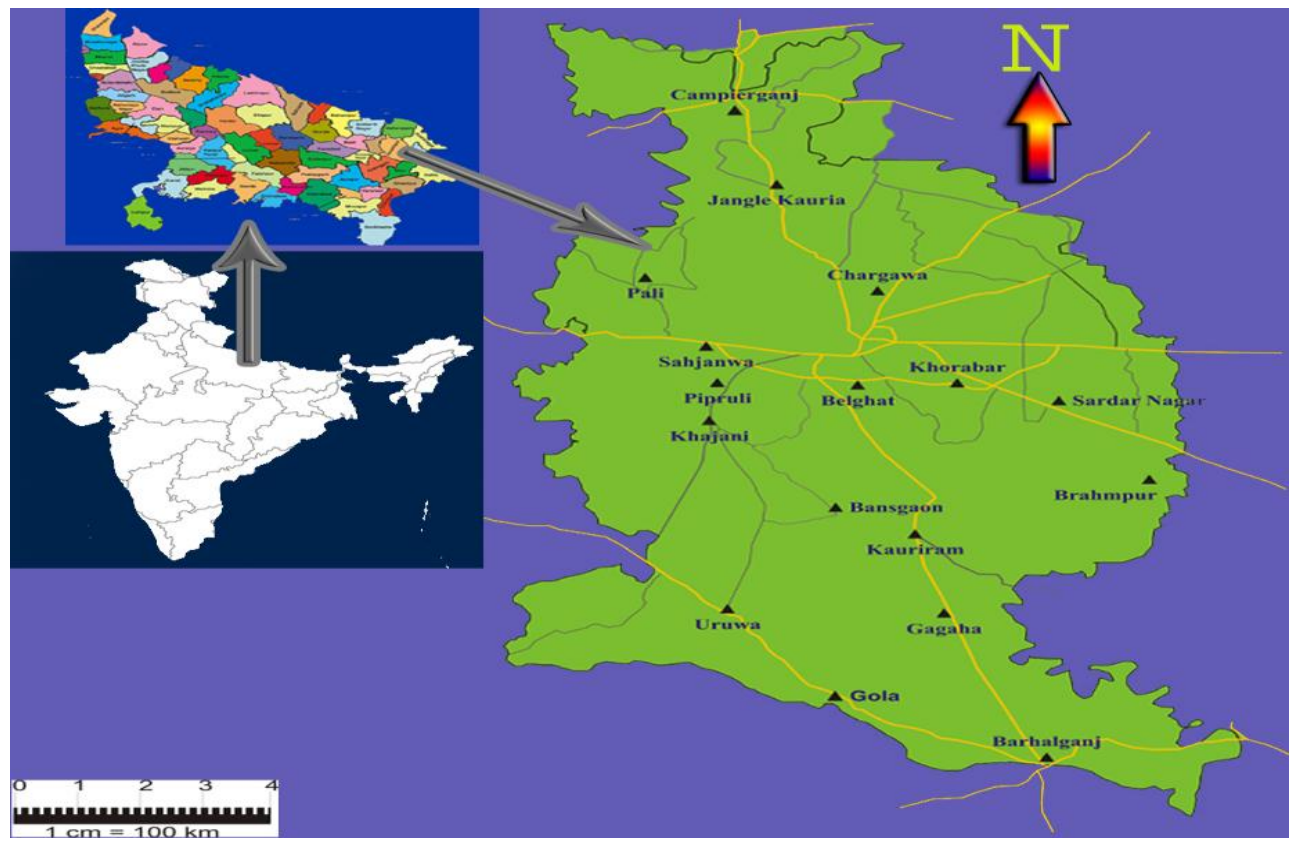

Fig.2 Collected samples of mushrooms.

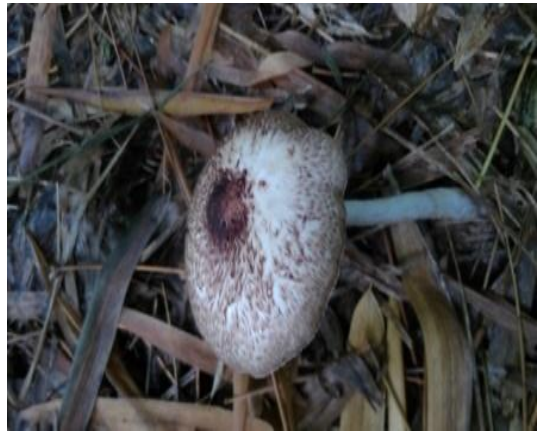

Agaricus arvensis

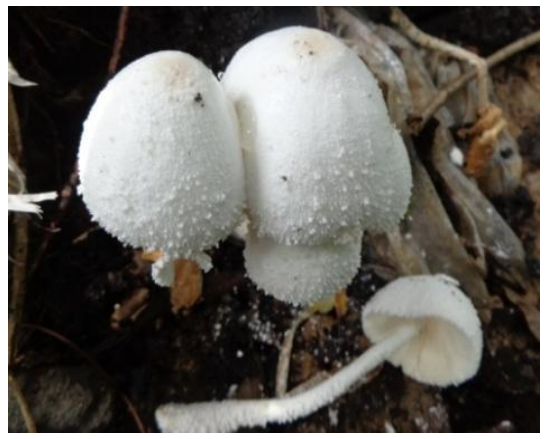

Amanita cokeri

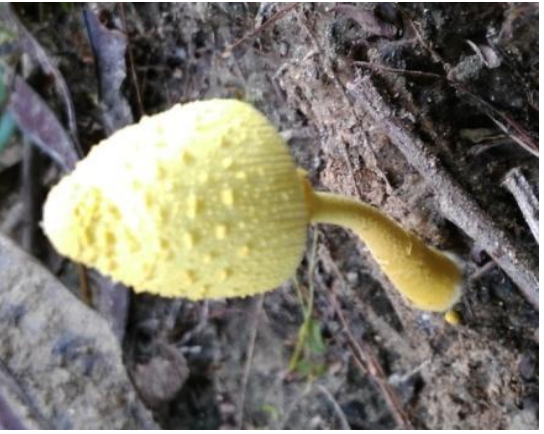

Agaricus trisulpharatus

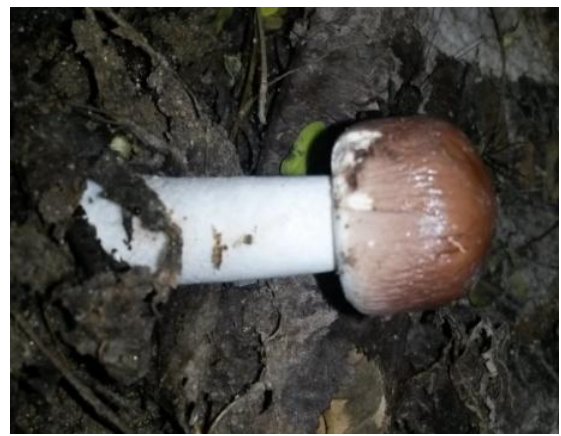

Amanita fulva

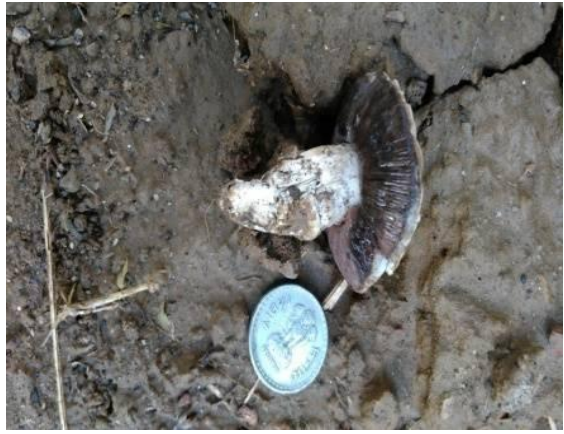

Agaricus campestris

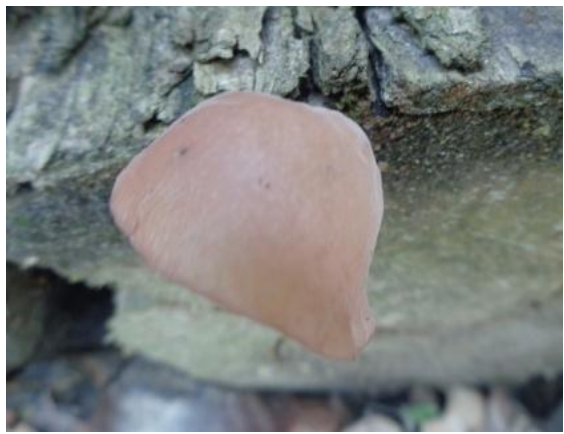

Auricularia auricula judae 


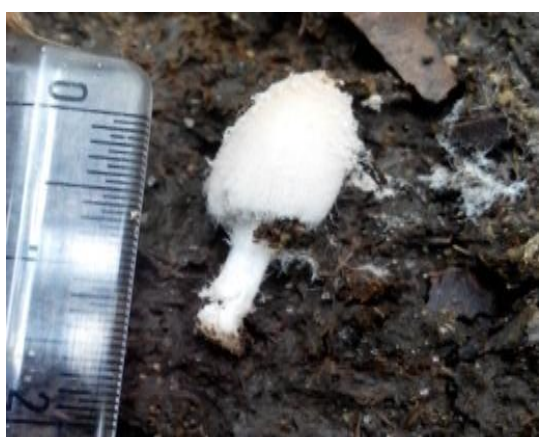

Coprinus comatus

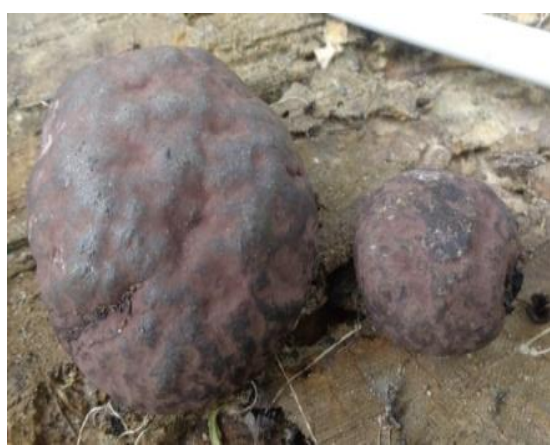

Daldinia concentric

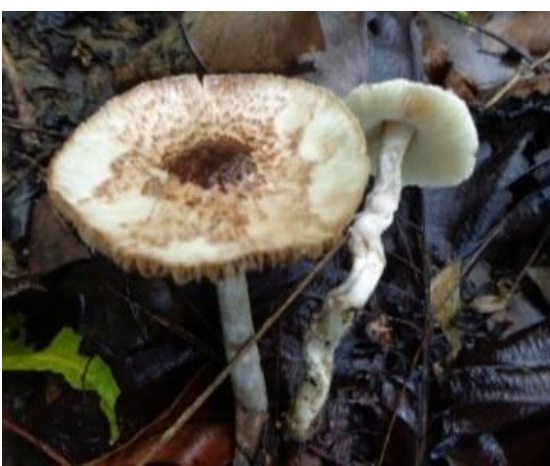

Leucoagaricus americanus

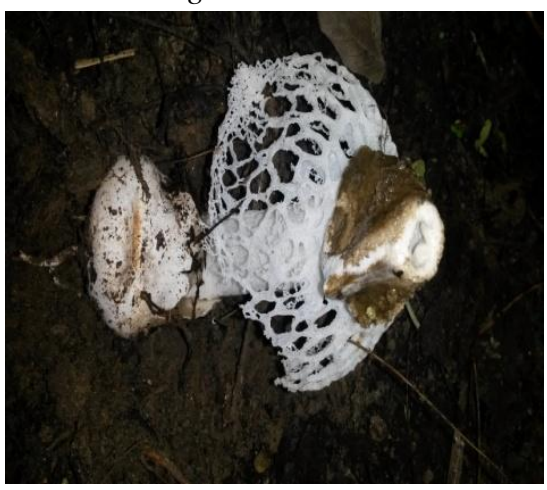

Phallus duplicates

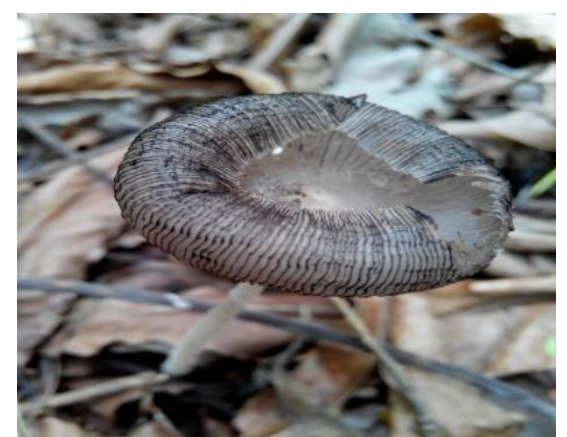

Coprinus extinctorius

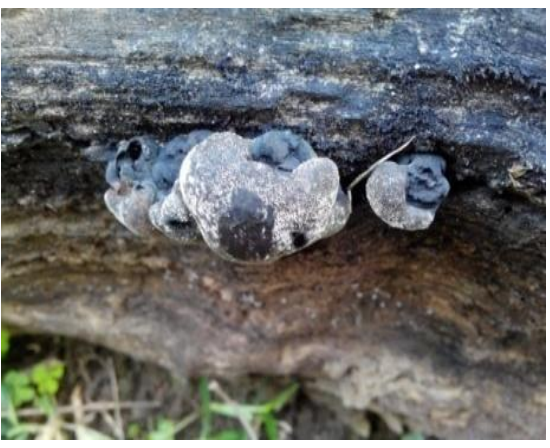

Daldinia vernicosa

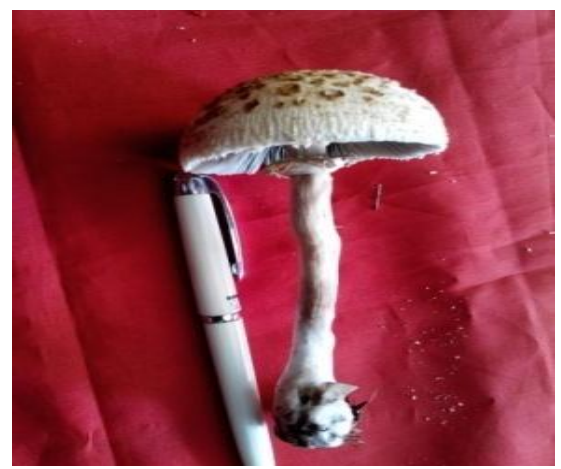

Macrolepiota rhacodes

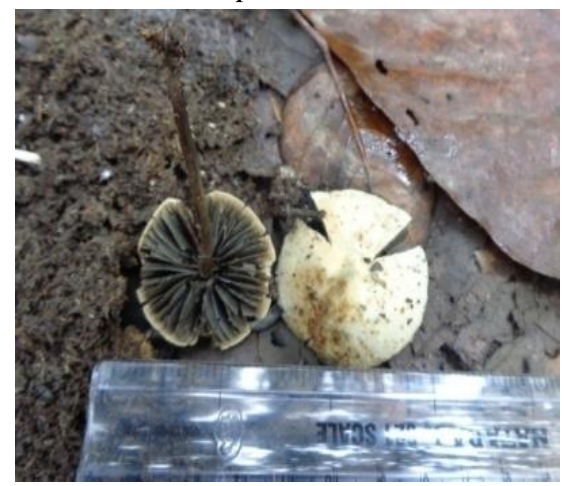

Panaeolus ater

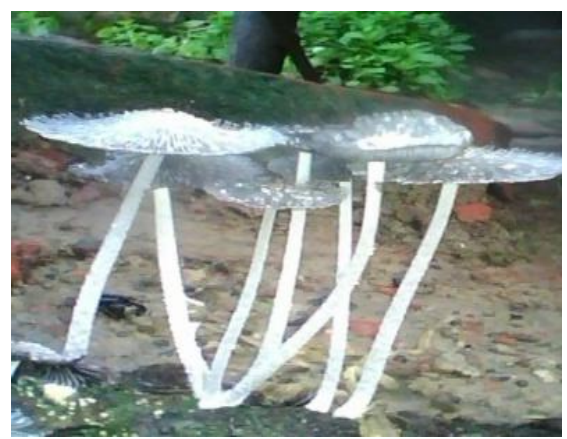

Coprinus domesticus

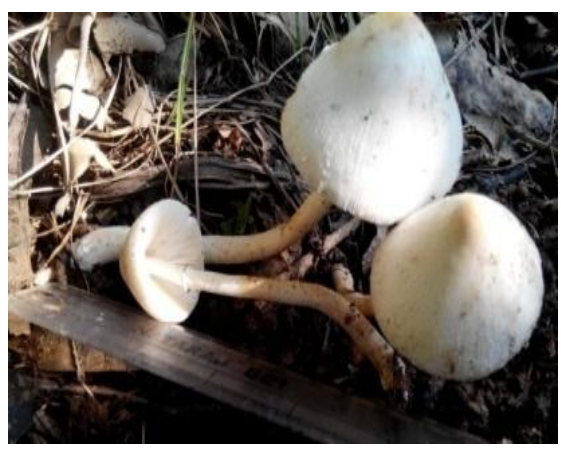

Leucoagaricus leucothites

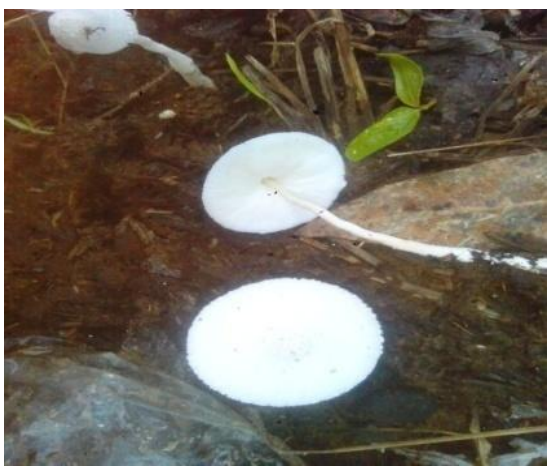

Macrolepiota procera

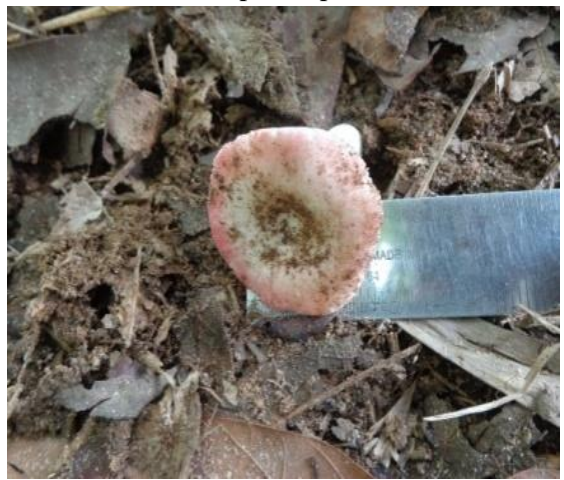

Russula emeticella 


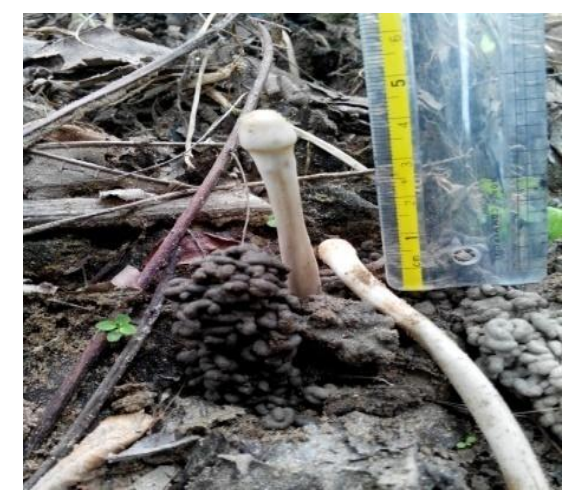

Termitomyces heimii

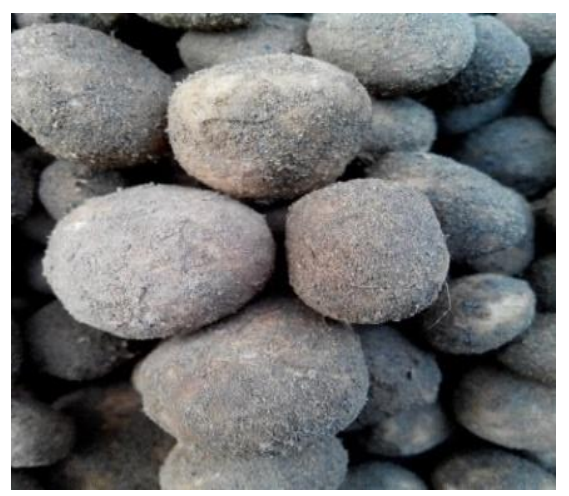

Tuber aestivum
There are several other workers who worked on mushroom diversity of Gorakhpur. Chandrawati et al., (2014) collected 29 macrofungal species belonging to 12 families in which Tricholomataceae was predominant. Out of 29 spp. collected 4 were excellently edible, 6 edible, 18 inedible and 1 poisonous. As a result of extensive field survey and microscopic studies in laboratory 12 taxa belonging to 8 families were identified earlier (Vishwakarma et al., 2014). In present study the survey was made between January, 2014-July, 2016, 20 different species of macrofungi belonging to 12 genera and 9 families were identified based on their morphology and microscopic characteristics. Out of 20 species identified 3 were excellently edible, 9 edible, 3 inedible, 4 medicinal and one was found to be poisonous. Termitomyces heimii, Tuber aestivum and Macrolepiota procera were edible and found to be abundant but Agaricus arvensis was rarely found during the survey.

In conclusion, macrofungi play a vital role in maintaining the ecosystem, they have high nutritional, medicinal potentials and also help in biodegradation and recycling of organic matter. Termitomyces heimii, Tuber aestivum and Macrolepiota procera were abundantly found to be edible and also used for medicinal and cooking purposes by tribals living near forest regions of the Gorakhpur. Identification of some unknown wild macrofungi opens a new way for researchers and pharmaceuticals to exploits them for food, medicines and the other bioprospects to attempt its commercial cultivation.

\section{Acknowledgement}

The authors thank UGC, New Delhi, for financial support and Head, Department of Botany DDU Gorakhpur University, Gorakhpur, for providing necessary laboratory facilities.

\section{References}

Alexopoulos, C.J., Mims, C.W. and Blackwell, M. 1996. Introductory Mycology. 4th ed. John Wilay and Sons, New York.

Arora, D. 2008. Notes on economic mushrooms: Xiao Ren Ren: the little people of Yunnan. Econ. Bot., 62: 541-544.

Bilgrami, K.S., Jamaluddin, Rizvi, M.A. 1981. The fungi of India part II (list and references). Today and Tomorrow's Printers and Publishers, New Delhi.

Bilgrami, K.S., Jamaluddin, Rizvi, M.A. 1991. The fungi of India part III (list and references). Today and Tomorrow's Printers and Publishers, New Delhi.

Butler, E.J. and Bisby, G.R. 1931. The Fungi of India. Imp. Counc. of Agri. Res. India, Sci., Mono 1, XVIII. Calcutta, 237.

Butler, E.J. and Bisby, G.R. 1960. The fungi of India. (Revised by R. S. Vasudeva). ICAR, New Delhi.

Chandrawati, Singh Pooja, Kumar Narendra, Tripathi, N.N. 2014. Macrofungal Wealth 
of Kusumhi Forest of Gorakhpur, Up, India. AIJRFANS, 71-75.

Crous, P.W. 2006. How many species of Fungi are there in tip of Africa. Studies in Mycol., 55:13.

Deshmukh, S.K. 2004. Biodiversity of tropical basidiomycetes as sources of novel secondary metabolites. In Microbiology and Biotechnology for Sustainable Development (ed. P.C. Jain,), CBS Publishers and Distributors, New Delhi, 121-140.

Gogoi, Y. and Sarma, T.C. 2012. An ethnomycological survey in some areas of Dhemaji district (Assam). The Ecoscan, 403-407.

Guzman, G. 2008. Hallucinogenic mushrooms of Mexico: an overview. Econ. Bot., 62: 404-412.

Harsh, N.S.K., Rai, B.K. and Ayachi, S.S. 1993. Forest fungi and tribal economy-A case study in baiga tribe of Madhya Pradesh (India), J. Trop. For., 270-279.

Hennery, E.D. and Sullivan, G. 1969. Phytochemical evaluation of some can Tharelloid fungi, J. Pharma Sci., 58(12): 1497-1500.

Manoharachary, C.S. 2002. Biodiversity, conservation and biotechnology of fungi. Presidential Address, Section-Botany, The $89^{\text {th }}$ Session of Indian Science Congress, Indian Science Congress Association, Lucknow, India, January 3-7, 2002.

Manoharachary, C.S., Singh, K.R., Adholeya, A., Suryanarayanan, T.S., Rawat, S., Johri, B.N. 2005. Fungal biodiversity: distribution, conservation and prospecting of fungi from India. Curr. Sci., 89:58-71.

Purakasthya, R.P. and Chandra, A. 1985. Manual of Indian Edible Mushrooms. Today and Tomorrow's Publication, New Delhi.

Rapsang, G.F. and Joshi, S.R. 2012. Bacterial diversity associated with Tungtap, an ethnic traditionally fermented fish product of Meghalaya, Indian J. Trad. Knowledge, 11(1): 134-138.

Sarbhoy, A.K., Agarwal, D.K. and Varshney, J.L. 1996. Fungi of India 1982-1992. CBS Publishers and Distributors, New Delhi.

Sitta, N. and Floriani, M. 2008. Nationalization and globalization trends in the wild mushroom commerce of Italy with emphasis on Porcini (Boletu sedulis and allied species). Econ. Bot., 62: 307-322.

Srivastava, B., Dwivedi, A.K. and Pandey, V.N. 2011. Morphological characterization and yield potential of Termitomyces spp. mushroom in Gorakhpur forest division. BEPLS, 1(1): 54-56.

Srivastava, S., Dvivedi, A. and Shukla, R.P. 2015. Commonness and rarity pattern of plant species with in Terai grassland of North Eastern Uttar Pradesh, India. Tropical Grasslands - Forrajes Tropicales, 3:161-186.

Vasudeva, R.S. 1960. The fungi of India (revised) I.C.A.R. New Delhi.

Vishwakarma, P., Singh, P., Mishra, P. and Tripathi, N.N. 2014. Diversity of Some Wild Mushroom from Gorakhpur, Uttar Pradesh, India. Int. J. Pharm. Life Sci., 5(7): 3643-3647.

\section{How to cite this article:}

Ravinder Pal Singh, Pratima Vishwakarma, Aradhana Pal and N.N. Tripathi. 2016. Morphological Characterization of Some Wild Macrofungi of Gorakhpur District, U.P., India. Int.J.Curr.Microbiol.App.Sci. 5(12): 207-218. doi: http://dx.doi.org/10.20546/ijcmas.2016.512.023 